\title{
The LXX Myth and the Rise of Textual Fixity*
}

\author{
Francis Borchardt \\ Lutheran Theological Seminary (Hong Kong) \\ 50 To Fung Shan Road, Shatin, Hong Kong \\ archaeology@gmail.com
}

\begin{abstract}
This brief study investigates the desire for a fixed textual form as it pertains to scripture in the Judean tradition. It particularly delves into this phenomenon in three early versions of the Septuagint origin myth. This paper argues that this myth is invaluable for the study of transmission and reception of scripture, as it is one of the earliest testimonies to the desire for a scriptural text to be frozen. By highlighting the ways the author of the Letter of Aristeas, Philo, and Josephus deal with the issue of textual fixity in the origin myth, this study aims to elucidate the range of opinions held by Judeans concerning the process of transmission of their holy books.
\end{abstract}

\section{Keywords}

Aristeas, Philo, Josephus, Septuagint

The myth ${ }^{1}$ of the origin of the LXX, known to us in various forms, is often investigated for its potential to shed light on the translation process, ${ }^{2}$ the

*) This study was prepared under the auspices of the EURYI project "The Birth and Transmission of Holy Tradition led by Juha Pakkala at the University of Helsinki. The group has provided funding and a setting for enlightening discussion.

1) The use of the term myth here should not be understood as derogatory or as a judgment about the objective truth or accuracy behind a story or belief. It should be understood, as Steven Grosby, "The Myth of Man-Loving Prometheus: Reflections on Philanthropy, Forethought, and Religion," Conversations on Philanthropy (2010): 11-24 at 12, defines the term: "an empirically unverifiable position."

2) Tessa Rajak, Translation and Survival: The Greek Bible of the Ancient Jewish Diaspora (Oxford: Oxford University Press, 2009), 27; Benjamin G. Wright III, Praise Israel for Wisdom and Instruction: Essays on Ben Sira, Wisdom, the Letter of Aristeas and the Septuagint 
Judean ${ }^{3}$ community in Alexandria, ${ }^{4}$ and attitudes toward the law book(s) that form the central plot device. ${ }^{5}$ The myth has proven itself a rich mine from which many deductions can be drawn in each of these areas. This study approaches the myth for its contribution to our understanding of the canonical and transmission process. Specifically we will investigate the various ways in which the different forms of this myth promote and contribute to the idea of textual fixity as an ideal in sacred and authoritative literature. We will argue that this represents an innovation on the part of the author, tradent, or community that preserves and transmits the myth by reacting against the custom of acceptance with regard to fluidity of textual form. ${ }^{6}$ Though we acknowledge that there are some cognate precursors to this attitude, we believe the position on textual form witnessed in the LXX myth is of a different species. In short, it is one of the earliest extant examples of reception of text(s) as scripture that holds not only the book, but also its exact contents and wording to be esteemed to the extent

(JSJS 131; Leiden: Brill, 2008), 279; Arie van der Kooij, "The Promulgation of the Pentateuch in Greek According to the Letter of Aristeas," in Scripture in Transition: Essays on Septuagint, Hebrew Bible, and Dead Sea Scrolls in Honour of Raija Sollamo (ed. Anssi Voitila and Jutta Jokiranta; JSJS 126; Leiden: Brill, 2008), 179-92, esp. 179.

3) We will use "Judean" throughout to refer to the socio-anthropological group often termed "Jewish," because the latter term in modern usage seems to imply at times much more, and at others much less about identity than the historical situation allows. Judean at this time is very likely a more accurate translation of the terms employed. Cf. S. Mason, "Jews, Judeans, Judaizing, Judaism: Problems of Categorization in Ancient History," JSJ 38 (2007): 457-512.

4) V. Tcherikover, "The Ideology of the Letter of Aristeas," HTR 51 (1958): 59-85; John R. Bartlett, Jews in the Hellenistic World: Josephus, Aristeas, The Sybilline Oracles, Eupolemus (Cambridge: Cambridge University Press, 1985), 14; John J. Collins, Between Athens and Jerusalem: Jewish Identity in the Hellenistic Diaspora (New York: Crossroad, 1986), 179-82; Judith Lieu, "Impregnable Ramparts and Walls of Iron": Boundary and Identity in Early 'Judaism' and 'Christianity'," NTS 48 (2002): 297-313.

5) Ian Scott, "A Jewish Canon Before 100 B.C.E.: Israel's Law in the Book of Aristeas," in Early Christian Literature and Intertextuality, Volume I: Thematic Studies (ed. Craig A. Evans and H. Daniel Zacharias; JSNT 391; London: T\&T Clark, 2009), 42-64. Martin Hengel, The Septuagint as Christian Scripture: Its Prehistory and the Problem of Its Canon (tr. Mark E. Biddle; Grand Rapids, Mich.: Baker, 2002), 11-12, 50-51, inter al.

6) The custom is even admitted by such maximalists as Roger Beckwith, "Formation of the Hebrew Bible" in Mikra: Text, Translation, Reading and Interpretation of the Hebrew Bible in Ancient Judaism \& Early Christianity (ed. Martin Jan Mulder and Harry Sysling; Assen: van Gorcum, 1988; repr. Peabody, Mass.: Hendrickson, 2004), 39-86, esp. 43, citing the evidence of Sifrei Deut 356. He would doubtless disagree with the broader conclusions this study will draw. 
that changes to the text are not permitted. The myth will be examined in three of its earliest forms. In the Letter of Aristeas we will observe the process by which the novel idea of an authoritative and fixed textual form is introduced. In Philo's De Vita Mosis, the inflexibility of the text and its importance to Philo's exegetical method will be displayed. When reading Josephus, we will discuss how some minor adaptations he makes to the myth turn the idea of textual fixity on its head.

The argument will proceed first with a definition of terms, particularly those relating to the canonical process. Following this, the biblical and extra-biblical precedents to this sort of reception will be discussed. We will then examine the ways the Letter of Aristeas, Philo's De Vita Mosis 2.25-44, and Josephus' Antiquitates 12.11-118 contribute to the idea of an unchanged and static textual form of scriptural texts. Finally, we will discuss the implications this might have for the study of the transmission of texts and the communities that contributed to them.

\section{Definition of Terms}

Because our argument that the desire for textual fixity is an innovation in the textual record relies on a specific notion of the nature of the received text, it is imperative that the terms employed in this argument have a very specific definition. We argue that the "laws of the Judeans" are received as scripture. We define scripture, with Eugene Ulrich as:

[A] sacred authoritative work believed to have God as its ultimate author, which the community, as a group and individually, recognizes and accepts as determinative for its belief and practice for all time and in all geographical areas. $^{7}$

Though one might quibble with one point or another of this definition (such as the requirement of divine origin), it establishes a strict set of boundaries and rigorous criteria a text must cross among an audience for it to be considered scripture. It is for this reason that we choose to employ Ulrich's terminology. Some scholars, such as Orlinsky, have a vague notion of "scripture" as indicated by a set of official actions and statements within

7) Eugene Ulrich, "The Notion and Definition of Canon," in The Canon Debate (ed. Lee Martin McDonald and James A. Sanders; Peabody, Mass.: Hendrickson, 2002), 21-35 at 29 . 
our records. Reading a text aloud before the people and subsequently having it approved of makes a text scripture. ${ }^{8}$ This sounds fine in general, but when it comes to specific examples, the proposition becomes dubious. For example, are we to suppose that 1 Macc 14:27-49 is received as scripture by the tradent who included in the account of Simon's reign as high priest? It might be the case, but it is difficult then to see what would separate scripture from any pronouncement given authority by a group of people. Other recommendations for defining types or even levels of reception among populations are perhaps more helpful. Robert Kraft's recommendation to use only the terminology employed by the sources concerning the texts they receive may fall into this category. ${ }^{9}$ The trouble here is that aggregation of information becomes nearly impossible. There is no assurance that one author's use of a specific term or phrase in reference to a book or collection denotes identical status as that of another author using the same vocabulary. This problem is complicated even further by the issue of using the ancient term in a modern context, where it may have very different connotations. That is, in the ancient context authors may have used "scriptures" to refer to a body of writings but not intended all the meaning that comes along with that term in a modern context. Moreover, this is not helpful when there is no vocabulary of reception employed by the ancient author, but a text is described. Thus, though we appreciate the variety of different models employed to define scripture and the various other types of texts, and certainly see the value in taking seriously the individual ancient testimonies to reception, we believe it best to use modern categories created ex-post in order to describe the reception of ancient literature. Ulrich's attempt is a rigorous example of such an approach, even if it can be limiting.

Perhaps as important for our purposes as defining scripture is defining other types of reception, which can be similar, but are not identical to scripture. First among these is an authoritative work:

An authoritative work is a writing which a group, secular or religious, recognizes and accepts as determinative for its conduct, and as of a higher order than can be overridden by the power or will of the group or any member. ${ }^{10}$

\footnotetext{
8) Harry M. Orlinsky, "The Septuagint as Holy Writ and the Philosophy of the Translators," HUCA 46 (1975): 89-114, esp. 96-97.

9) Robert Kraft, "Finding Adequate Terminology for 'Pre-canonical' Literatures," n.p. [cited 8 August, 2011]. Online: http://ccat.sas.upenn.edu/rak/SBL2007/canon.

10) Ulrich, "Notion," 29. The emphasis is retained from the original.
} 
We might amend Ulrich's definition here slightly by dropping the requirement for determination of conduct, as this appears to be unnecessarily limiting. There are many types of authority a given work can retain and they need not all affect one's conduct. Some writings might tell what is understood as the authoritative history of a dynasty, a people, or a ruler and be revered for their quality. Other treatises might gain authority because of the teachings they contain, even if these teachings are not binding but are repositories of wisdom.

With this small emendation it is clear where an authoritative text differs from a scriptural text, though indeed, all scriptural texts are by definition also authoritative. Scripture has a sacral quality in that holiness is attached to it. It also is recognized as having its source in God, though this might be through inspiration or reflection than divine dictation or even scribal activity. It is also recognized as determinative for conduct in all times and places, rather than being occasional or arbitrary.

Now that the distinction is clear between authoritative and scriptural texts, we should also note that the presence of scripture does not necessarily denote canon. Ulrich understands the canon of scripture to be:

[T] he definitive list of inspired, authoritative books which constitute the recognized and accepted body of sacred scripture of a major religious group, that definitive list being the result of inclusive and exclusive decisions after serious deliberation. ${ }^{11}$

Ulrich's definition highlights the fact that the canon is primarily a definitive collection of books of sacred scripture that is the result of conscious decision-making concerning which belong and which are excluded. By definition, this places it at a perceived end point in the process. Though there may be several editions of "canon," successive generations must make what they believe is the final decision on the books included. This definition does not rule out previous collections of scripture that are openended, ${ }^{12}$ nor does it deny the existence of libraries including possibly

11) Ibid., 29.

12) E.g. at Qumran, if we can even speak of these texts as a collection and/or tie them to any one community. Both points are significantly open for debate. A less debatable position would be the literature cited by Ben Sira's descendant in the translator's prologue to Sirach. There are clearly demarcated "collections" in the author's conception. He also obviously believes them to be open-ended, as he argues that he and his grandfather are both contributing to these collections. 
scriptural or authoritative works without a conscious decision about their contents. ${ }^{13}$ The definition does importantly distinguish between these bodies of literature and canon however. Canon is the capstone of a long process and should not be confused with other collections, and most importantly should be clearly separated from scripture. In all our examples, as we shall see, there is little indication of canon.

Finally, let us define textual fixity as a uniform textual appearance down to the word. When we speak of the desire for textual fixity, we presume the community or individual aspires to a formally frozen copy that not only communicates the same stories and material, but does so in the same order with the same words. ${ }^{14}$ This might reach its most extreme form in the Masoretic tradition, wherein letters and even accents are preserved, but textual fixity need not be so fastidious as that. It should be noted that though the form of the text exists largely outside the canonical process, it is not totally unrelated. One cannot place it at any one point, such as when the text becomes scripture, authoritative, or included in the canon, but the desire for textual fixity seems to correlate with texts that fall into those categories. It is part of the transmission process that is naturally aligned with a text's authority, divine origin, or inclusion within an official collection. Though the text may take many forms in reality, it is not hard to understand that the desire might arise for attention to be paid to the words themselves when the texts exert some authority over their audience. In such cases a particular community might only accept one form of a text as authentic, even if it acknowledges there are multiple versions.

\section{Precursors to Textual Fixity}

Two commonly cited indications of the desire for a stable textual form come from Deut 4:2 and 13:1. The relationship between these two similar

\footnotetext{
13) A library of this sort might be witnessed in 2 Macc 2:13-15 if the story is not completely fictional. Those who see the canon present in this text are begging the question. Cf. Armin Lange, "2 Maccabees 2:13-15: Library or Canon?" in The Books of the Maccabees: History, Theology, Ideology. Papers of the Second International Conference on the Deuterocanonical Books, Pápa, Hungary, 9-11 June, 2005 (ed. Géza Xeravits and József Zsellengér; JSJS 118; Leiden: Brill, 2007), 155-68.

14) James A. Sanders, "The Issue of Closure in the Canonical Process," in The Canon Debate (ed. Lee Martin McDonald and James A. Sanders; Peabody, Mass.: Hendrickson, 2002), 252-63, esp. 256, terms this verbal inspiration, which he differentiates from the looser dynamic inspiration of the message and the more strict literal inspiration of even the letters.
} 
texts has been long discussed. Some scholars, such as Timo Veijola, have argued that 13:1 is a later insertion into Deuteronomy which traces its lineage back to 4:2, where the sentiment is expressed more thoroughly. ${ }^{15} \mathrm{In}$ his case even 4:2 is an addition in its context. On the other side, Bernard Levinson has argued that $13: 1$ is original to its context and is later expanded by the tradent responsible for Deut 4:2. ${ }^{16}$ The basis for this observation is that, in its context, 13:1 works in the same way as does the injunction against adaptation in Esarhaddon's succession treaty. In fact, Levinson sees Deut 13:1 as a subversion of the treaty in order to create a rival pact in the Judean context. ${ }^{17}$ It is beyond the scope of this study to take sides in this debate. It is enough to note that a wealth of scholarly opinion sees these texts as related, and even noting their nature as possible additions, sees them as far earlier than the passages we will discuss.

So, why are these not of the same species as the sentiments in the LXX myth? First, if we examine the function of these verses in their context, it becomes clear that they do not affirm the authority of the text under discussion. Rather, they employ a formula widely used in Greek and Near Eastern contexts that tries to stem the current of frequent and open textual emendation. ${ }^{18}$ That is, these verses make no statement about reception. They provide little clue as to how the text in question was received. They merely purport to express the wishes of the author that the commands he gives be carried out in their fullest form. Since the desire for textual fixity as it relates to authoritative and scriptural texts is primarily a question of reception, these verses provide little insight.

Even if it is correct that these verses are later additions, as Veijola remarked, and thus imply some sort of reception, there is no indication that the material to which they refer is textual in nature. Surely הדבר is mentioned in both 4:2 and 13:1, but the type of changes listed by the

\footnotetext{
15) Timo Veijola, Das 5. Buch Mose Deuteronomium (ATD 8,1; Göttingen: Vandenhoeck \& Ruprecht, 2004), 113-14.

16) Bernard M. Levinson, "The Neo-Assyrian Origins of the Canon Formula in Deuteronomy 13:1," in Scriptural Exegesis: The Shapes of Culture and the Religious Imagination. Essays in Honour of Michael Fishbane (ed. Deborah A. Green and Laura S. Lieber; Oxford: Oxford University Press, 2009), 25-45, esp. 35-36.

17) Ibid., 37.

18) Armin Lange, "Nobody Dared to Add to Them, to Take from Them or to Make Changes' (Josephus, $A G$. AP. 1.42): The Textual Standardization of Jewish Scriptures in Light of the Dead Sea Scrolls," in Flores Florentino: Dead Sea Scrolls and Other Early Jewish Studies in Honor of Florentino García Martinez (ed. Anthony Hilhorst, Émile Puech, and Eibert Tigchelaar; JSJS 122; Leiden: Brill, 2007), 105-26 at 106.
} 
tradent could just as easily refer to interpretations or adaptations of the message as they have been interpreted to refer to the text in later times. There is no clue about the textual form at all. If one examines the situation from the outside, it seems puzzling to deduce that the author of these verses desires a stable textual form while simultaneously making innovations to the text.

The third and final reason these verses might be different relies on their relationship to the Neo-Assyrian cognates. Even if Levinson is incorrect in tying 13:1 with the verses following it to the succession treaties of Esarhaddon, it cannot be denied that the formula itself has roots in the NeoAssyrian treaty form, as shown by Moshe Weinfeld. ${ }^{19}$ The fact that it is used in such documents means that, if it is not simply repeated a formulaic part of the treaty form, it is likely used because the text in question is held in similar regard to those treaties. The Neo-Assyrian treaties, like whatever commands are included in these verses in Deuteronomy, were no doubt authoritative texts for some of their audience, but likely do not meet the criteria for scripture. They are occasional as opposed to eternal and have a limited command over the conduct of those under their sway. This point is especially damning for the Assyrian treaties, as they obviously had no claim to divine origin, and thanks to a fuller historical record, can be pointed to as having a limited reach. It is nearly as difficult to demonstrate the authority whatever text is in question here held over its audience, whoever they were, especially considering the archaeological and textual record.

Turning to the later biblical evidence, one recognizes rather quickly that there is little of substance with which to compete. Ecclesiastes 3:14 obviously refers to divine acts and not to a text of any sort. Another text oft cited, Eccl 12:11-13 does mention the large amount of books being dangerous sources of practice, but seems to argue for a concentration on divine commandments and the sayings of the teacher more than it makes a case for a specific textual form of those sayings or commandments. It is a verse perhaps more useful in discussions of scripture or authority. Sirach 42:20-21 is a wonderful reflection on the omnipotence and omniscience of the divine being which uses some literary imagery. It is a stretch though to see any reference to any specific text, let alone a single form of that

19) Moshe Weinfeld, Deuteronomy and the Deuteronomic School (Oxford: Oxford University Press, 1972), 261-65. 
text. Likewise, Sir 18:6 has little to do with the form of literary output, concentrating instead on divine works. Jeremiah $26: 2$ clearly speaks of an oral context and concerns prophetic words, rather than a literary work. The other uses in Jer 26 also fall into this category. Proverbs 30:6 very obviously refers to divine words, but it is unclear whether they are reported in oral or written form, and whether verbal stability is called for. In all these cases one would have to investigate these texts looking for proof of the desire for textual fixity in order to find traces of it. We believe these texts give evidence of the trend toward a desire for stabilization of teachings, but they do not extend to textual fixity of a work considered to be scripture.

\section{The Desire for Textual Fixity in the LXX Myth}

\section{The Letter of Aristeas}

Because the LXX myth exists in several different accounts and each has disparate emphases we will discuss each of the early versions separately. Though all these editions are close enough to be properly seen as the same story, there are enough differences, especially when it comes to their attitudes toward scripture, that they provide interesting points for comparison. One of the earliest extant accounts of the origin of the LXX is doubtless found in the Letter of Aristeas. ${ }^{20}$ Even if the fragmentary account attributed by Eusebius to Aristobulus the Judean peripatetic is earlier, it hardly presents us with enough material regarding the myth itself or the nature of the text to merit discussion. ${ }^{21}$ Further, Aristeas ${ }^{22}$ appears to be the basis for both Philo's account in De Vita Mosis 2.25-44, ${ }^{23}$ and Josephus' version of the story in Antiquitates 12.11-118. ${ }^{24}$ Therefore it is fitting that we should start our examination with this treatise.

\footnotetext{
20) Rajak, Translation, 34, notes that it is unknown whether Aristeas or Aristobulus was the first to write down an account of the LXX translation. She also speculates as to whether one drew upon the other or they were both influenced by a common oral source.

21) The fragments are found in Eusebius, Praep. ev. 12.12.1-2.

22) We will use Aristeas as shorthand for the author or the work itself interchangeably. If we make reference to the character it will be explicitly made known.

23) Paul Wendland, "Zur ältesten Geschichte der Bibel in der Kirche," ZNW 1 (1900): 26790, esp. 269-70.

24) Giuseppe Veltri, Libraries, Translations, and "Canonic" Texts: The Septuagint, Aquila, and Ben Sira in the Jewish and Christian Traditions (JSJS 109; Leiden: Brill, 2006), 40.
} 
Since definitions are so important to our case, we will first demonstrate that the books under consideration meet the criteria outlined by Ulrich for scripture. We will recall that this requires the work to be considered sacred, authoritative, of ultimate divine authorship, and applicable to the whole community for all time and in all geographical areas. The texts in question

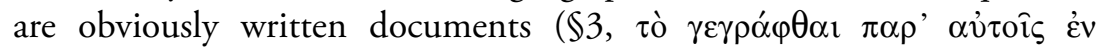

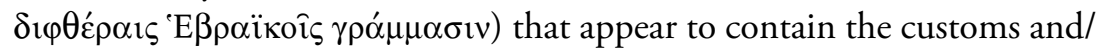

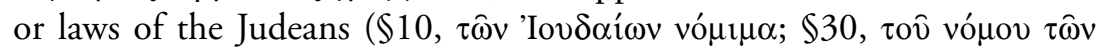

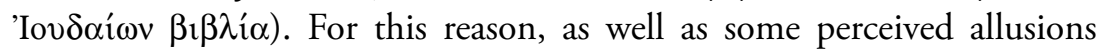
many scholars have surmised the texts were some version of the Pentateuch. ${ }^{25}$ When we look at the bare evidence without prejudice we cannot conclude what the specific contents of this text were for our author or his imagined community more than that it was some collection of laws that seem to be attributable to Moses $(\$ 144){ }^{26}$

Despite this lacuna the status Aristeas envisions for the text is unambiguous. The sacral character of the text is ensured in several instances. First, they are in the possession of the high priest, Eleazar $(\$ 3)$. Second, the texts are explicitly said to have a "sacred and religious Weltanschauung"

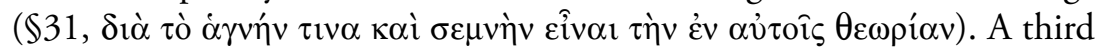
proof of the sacred character of the text is that the high priest calls the law itself holy ( $\$ 45, \tau$, ov $\dot{\alpha} \gamma i$ ív vómov). It is evident by the context that he conceives of it in textual form $(\$ 45-46)$, so there is no danger here of the law being holy, but the text being extraneous. The final point in which the text is shown to be sacred for Aristeas is that both Ptolemy Philadelphus ( $\$ 177$, $317)$ and the Judean community of Alexandria $(\$ 310)$ greet the law with reverence and pay homage to it. This occurs both in its Hebrew and Greek forms! There is no question that for our author, the text is sacred. It seems almost redundant to prove that this sacred text is also authoritative, but let us add a single proof on this note. In Eleazar's apology for the law he clearly sees it as holding great sway over the people's conduct in everyday life, noting that it creates impregnable ramparts and walls of iron around the people (\$139-142). Eleazar goes on to note that this marks off the

\footnotetext{
25) E.g. Wright, Praise, 275 n. 2, 280.

26) There are several specific laws listed, such as dietary taboos, purity laws, and the use of various items such as mezuzot, prayer shawls, and phylacteries that could lend some clues. However, if one is thoroughly empirical, one must admit the possibility of these laws being known in a separate form or even document than their current locations.
} 
Judeans as men of god among the Egyptians. The law plainly influences the conduct of the community, and is therefore authoritative.

The question of ultimate divine authorship is ambiguous, but ultimately answered in the positive. Though Moses is singled out as the legislator explicitly on one occasion $(\$ 144)$, a human legislator is implied at several other points $(\$ 131,139)$, and the agency of the mortal interpreters is emphasized $(\$ 39,302,308)$, it is evident that the author of Aristeas considers there to be a divine source behind the text. Demetrius of Phaleron remarks on the divine origin of the law $(\$ 31)$. Ptolemy likewise shows respect to the scrolls because he understands the oracles to be divine $(\$ 177)$. Even Eleazar, when attributing the law to a human author concedes that he was especially endowed by God to understand all things (\$139). Therefore, though there is certainly a great degree of human agency in the production of the text in Aristeas, the true source is divine.

The last criterion for a text to be considered scripture in Ulrich's definition, that it be considered applicable to the whole community for all time and in every place, is perhaps easiest to demonstrate. The fact that the law is applied to Judeans living in Alexandria as well as those at home opens the possibility that the law applies everywhere. The desire to make it more widely available to the Alexandrian community through translation also supports this contention. The idea that the law is applicable to the people eternally may be communicated by the fact that the law seems to preserve the people in purity and separation from the rest of the world (\$139-142). If there were any divergence from the law in the past or any in the future this might harm that purity. So, it is a significant possibility that the law is eternally applicable.

It has been shown that the law in the Letter of Aristeas meets our stringent requirements for being considered scripture. Now, let us examine the instances in which a concern for textual fixity is displayed. The most obvious, and most often noted by scholars, is the explicit decision in $\$ 310-311$ to allow no further changes to the text:

After the books had been read, the priests and the elders of the translators and the Jewish community and the leaders of the people stood up and said, that since so excellent and sacred and accurate a translation had been made, it was only right that it should remain as it was and no alteration should be made in it. And when the whole company expressed their approval, they bid them pronounce a curse in accordance with their custom upon any one who should make any alteration either by adding anything or changing in any way 
whatever any of the words that had been written or making any omission. This was a very wise precaution to ensure that the book might be preserved for all the future time unchanged. ${ }^{27}$

Unlike the previous examples from the "biblical" corpus there can be no doubt what is intended here. There is a specific collection of books, which have attained a certain form that was so excellent and acclaimed, that nothing in it was lacking or deserving of emendation. The curse that follows specifically indicates that it is not only the general message, but also the written words themselves that should eternally be preserved. There is a hint in this section that the impulse to make such a curse is customary among the people. It is likely a reading of Deut 4:2 or 13:1. However, as Giuseppe Veltri has pointed out, "in Deuteronomy, the focus is the observance of the Torah, without stress on possible divine copyright; in Aristeas, the accent is on the preservation of the Torah without changing the text." 28 This is an important difference that is central to our hypothesis. For perhaps the first time in written record, ${ }^{29}$ an author expresses the desire that a text version considered to be scripture be frozen. By doing so, Aristeas both acknowledges the status quo ante of fluid textual transmission and anticipates the desires of later scribes and scholars to reach an authoritative version. It is unfortunately unclear whether his rereading of Deuteronomy is an innovation on the part of the author, or was a current trend among the Judean or broader Hellenistic community of that time and place. However, it is evident that Aristeas wishes to portray this as a major contribution of the LXX project.

The author hints at this desire for a frozen textual form earlier in the text at numerous places. The first of these comes at $\$ 30-32$ in an ostensible decree from Demetrius to the king. He writes:

27) Translations of the Letter of Aristeas come from The Pseudepigrapha (English) Translated by Craig A. Evans, assisted by Danny Zacharias, Matt Walsh, and Scott Kohler. Acadia Divinity College, Wolfville, Nova Scotia CANADA. Portions also translated by Daniel Christiansen. Copyright (C) 2009 by OakTree Software, Inc. Version 2.4.

28) Veltri, Libraries, 36.

29) Most scholars, e.g. Rajak, Translation, 34, date the Letter to the latter half of the $2 \mathrm{~d}$ century B.C.E., but there is relatively little to firmly date the text, so it could be anytime between the $3 \mathrm{~d}$ century B.C.E. and the 1 st century C.E., when Philo and Josephus seem to use it as a source. However, Elias Bickermann, "Zur Datierung des Pseudo-Aristeas," ZNW 29 (1930): 280-98 sets the range much tighter on linguistic and geographical grounds: c. 145-125 B.C.E. 
The books of the law of the Jews (with some few others) are absent from the library. They are written in the Hebrew characters and language and have been carelessly interpreted, and do not represent the original text as I am informed by those who know; for they have never had a king's care to protect them. "It is necessary that these (books) should be made accurate for your library since the law that they contain, in as much as it is of divine origin, is full of wisdom and free from all blemish. For this reason literary men and poets and the mass of historical writers have held aloof from referring to these books and the men who have lived and are living in accordance with them, because their conception of life is so sacred and religious, as Hecataeus of Abdera says. "If it please you, O king, a letter will be written to the High Priest in Jerusalem, asking him to send six elders out of every tribe-men who have lived the noblest life and are most skilled in their law-that we may find out the points in which the majority of them are in agreement, and so having obtained an accurate translation may place it in a conspicuous place in a manner worthy of the work itself and your purpose. May continual prosperity be yours!"

According to Benjamin Wright, the clause about the text being "carelessly

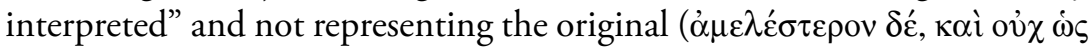
vं $\alpha \rho \chi \varepsilon 1, \sigma \varepsilon \sigma \eta \dot{\mu} \mu \nu \tau \alpha \mathrm{l}$ ) should be rendered as "they have been transcribed somewhat carelessly and not as they should be." ${ }^{30} \mathrm{He}$ argues, conclusively in our opinion, that the context shows total interest in the Hebrew text, and therefore must be referring to transcription rather than translation. If this is the case, the text astoundingly acknowledges that the Hebrew textual editions are corrupted. ${ }^{31}$ The reason given, as is likely correct for this point in Judean history, is that there has been no king to act as steward over the texts. This is supported by the solution proposed: to have legal scholars sent from Judea to debate the finer points of the law so as to achieve an accurate translation. There is, in Aristeas' view, no authoritative (here used with a distinct meaning from that of Ulrich) version of the law. Astoundingly, the author sets up Demetrius as the source of the will to establish a fixed form of the text. For Demetrius (and perhaps Ptolemy as well), this desire applies to all texts, as $\$ 29$ demonstrates when discussing the general commission to gather all books and repair the defective books. It seems

30) Wright, Praise, 306. Emphasis added.

31) Cf. D.W. Gooding, "Aristeas and Septuagint Origins: A Review of Recent Studies,"

VT 13 (1963): 357-79. 
that Demetrius and Ptolemy by extension want perfect copies for the library, and therefore apply that standard to the Judean laws as well.

The Ptolemaic provenance of the desire for a standard text is again underlined at $\$ 39$. The king has a letter drafted in which he requests from Eleazar to send sages of the highest quality, who seemingly are intended to represent the whole Judean community. ${ }^{32}$ These men are required, as Demetrius suggested to the king initially, to be "skilled in your law and able to interpret it, that in questions of dispute we may be able to discover the verdict in which the majority agree." Again, Ptolemy's goal appears to be creating a consensus edition of the text through a method of careful interpretation and deliberation. Whether one agrees with the method proposed for attaining an authoritative version is secondary to the point. What is important for our purpose is that the impulse for a text worthy of being fixed is made to come from the Hellenistic monarch, or at least his court. ${ }^{33}$ The closing statement of this paragraph, expressing the hope of glory on account of this work recalls that the production of this sort of text of the Judean law (in Greek? See below) is an innovation. When the work is completed under the direction of Demetrius, it is confirmed that the method he initially proposed is employed (\$302). The translators work separately (or in separate groups) and compare the results in order to make them agree. Demetrius is then said to copy down the result.

Throughout the text, until of course the climactic scene of approval above, the Judeans show little initiative in the creation of a fixed textual form. Though plurality or corruption of texts is previously acknowledged, it is evident the Judeans either have no concern for this situation or no means to correct it until Ptolemy inserts himself. This does not necessarily mean that Aristeas did not envision the existence of a reliable or authoritative Hebrew text, however. The provenance of the Hebrew version of the

\footnotetext{
32) Sylvie Honigman, "The Narrative Function of the King in the Letter of Aristeas," in Jewish Perspectives on Hellenistic Rulers (ed. Tessa Rajak et al.; Berkeley: University of California Press, 2007), 128-46, esp. 133, suggests that this point is made by analogy both to Judean history in the tribes and to Hellenistic culture in the selection of elders. Whether the theory is true in all its intricacies is unimportant. It is only necessary to point out that there is ample support for these representing the whole community.

33) This might be tied to the Alexandrian schools of Homeric scholars who attempted textual criticism in order to find the true Homeric works in the myriad interpolations. Cf. Maren R. Niehoff, "Questions and Answers in Philo and Genesis Rabbah," JSJ 39 (2008): 337-66, esp. 360. It might also be tied to the well-known stories of Ptolemy's desire for the books of highest authority and quality for the Museum. Cf. Honigman, "Narrative," 136-37.
} 
laws in the temple $(\$ 46)$, as well as the decoration, and craftsmanship of the scrolls (\$176) may indicate that the author means to present these as "reliable versions" of the law. ${ }^{34}$ It may also be that these multiple scrolls contain manifold versions of the same law, rather than separate works included under the heading of law.

Though one cannot definitively prove the case in either direction, it is worthwhile to be aware that the LXX might be the first authoritative Greek version for Aristeas, instead of the first truly authoritative version of the law. In any case, as Aristeas presents the origin myth, it is the Greek edition produced in Alexandria that is first fixed not only in its message, but also its textual form. The concern for this level of control over the text seems to stem almost entirely from the Hellenistic court. De Crom is likely correct in ascribing this text-centered approach to the law to the Greek mindset, and placing it alongside the quality of the translators, king, Hebrew version, and acclamation by the community as proofs of the text's authority. ${ }^{35}$ It is novel in the literary record that the preservation of a fixed and, for lack of a better term, reliable textual edition is cited, for this or any other purpose.

\section{De Vita Mosis 2.26-45}

Here it is hardly necessary to exhaustively affirm Philo's reception of the text as scripture. We'll only note that 2.27 ensures that the legislation of Moses has been respected by the community from time immemorial so that it has dictated the actions of that community throughout its history. Philo also presents these texts to be sacred and of ultimate divine authorship in 2.34 when he notes that they are "divinely given by direct inspira-

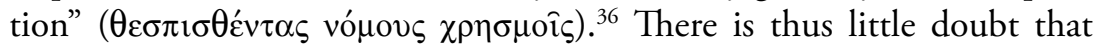

\footnotetext{
34) Wright, Praise, 283, writes that these qualities as well as the king's show of obeisance ensure the divine nature of the Hebrew. It should be noted, however, that the king is clearly honoring the contents of the scrolls, rather than their actual form; Gooding, "Aristeas," 360 , gives a similar line of reasoning.

35) Dries De Crom, "The Letter of Aristeas and the Authority of the Septuagint," JSP 17 (2008): 141-60. We do not necessarily agree with all De Crom's conclusions about how these different aspects function to confer authority upon the LXX, especially given his lack of reference to the emergent nature of authority, but we do agree with the principle that they function as proofs.

36) Translations of Philo's Life of Moses are provided by The Works of Philo, Completed and Unabridged. New Updated Edition. Translated by C. D. Yonge. (Peabody, Mass: Hendrickson,
} 
Philo receives the laws of Moses as scripture for the Judeans in this version of the LXX myth. This is perhaps of little surprise as Philo is active so much later than the author of Aristeas and likely knows his version of the myth, but it is important for our argument to ensure it meets the definitions with which we are working.

Now we may move on to discuss how Philo deals with the desire for textual fixity in his edition of the origin myth. In many ways, he raises the level of stabilization of the LXX text, but along the way he diminishes the importance of the Ptolemaic publication for the standardization of the text. We witness this first early in the text. At 2.26-27 there is an indication that the language and laws have remained unchanged since they were first written down in the language of the Chaldeans. In this case, it appears as though it is not necessarily the text that remains unchanged, but only the language and observance. However language here may include the exact wording within its concept as well. This is suggested by a clue slightly later. The translators, according to Philo, were not permitted "either to take away anything, or to add anything, or to alter anything, but were bound to preserve the original form and character of the whole composi-

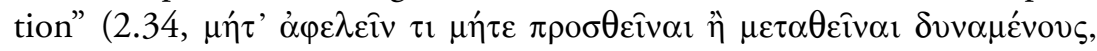

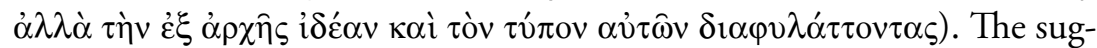
gestion is that the Hebrew version of the law is already considered to be fixed in content and form. The task of the translators is made nearly herculean because they must essentially reproduce a text already considered perfect in another language. Philo gives the impression that the Hebrew laws have a definite and recognized textual form. If the Hebrew were not fixed, to what could the LXX translation be compared? Even if Philo is allowing for multiple Hebrew forms to exist, he certainly wishes to endorse one as the "authentic" version, which cannot be changed just as the Greek admits no flexibility. The fixed form of each depends on the other by Philo's own logic.

By making this change Philo's version of the myth raises the stakes of the translation project. Instead of correcting a pluriform text and producing a consensus edition, as in the Letter of Aristeas, the translators are tasked with making changes, but limiting the adaptation only to the language. These translators must preserve all the other qualities. Luckily for them, Philo

1993). The phrasing here, though imperfect, does a good job conveying the meaning of a tricky phrase. 
provides a bit of divine help in taking on this commission. After requesting divine aid for the translation they are described:

like men inspired, prophesied, not one saying one thing and another another, but every one of them employed the self-same nouns and verbs, as if some unseen prompter had suggested all their language to them.

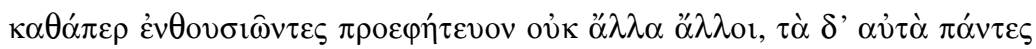

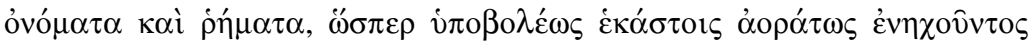
$(2: 37)$

From this description it is obvious that Philo deals with the problem of translating a fixed work of scripture the only way possible: the translation itself must also be divinely inspired. Instead of producing a critical edition through the cooperation of the best legal scholars Judea had to offer, human agency is essentially removed by Philo. God has provided the words and transferred the sense and form of the text into a new language. Scripture, which accordingly to Philo was in a fixed form, remains so through this miracle (2.40). The extraordinary nature of the event is not lost on Philo, as he points out the various ways meanings can be conveyed between languages (2.38-39). It is obvious from this that Philo wishes to convey that a fixed text is essential for scripture. He moves the authorized version out of the hands of gentiles, and really out of the purview of humans altogether, and transfers the production of a fixed textual form to the realm of the divine. For Philo it may be that this is his justification for reading the LXX instead of the Hebrew. ${ }^{37}$ In any case, we have witnessed a marked increase in the extent to which textual fixity is important for scripture in Philo's De Vita Mosis.

This may not be a major surprise considering the way Philo treats scripture elsewhere and his employment of the Alexandrian exegetical method. According to Adam Kamesar, the revelation contained in scripture comes by means of a two-stage process for Philo. First, Moses receives revelation non-verbally, and then Moses, with the help of intellect communicates the revelation in the form of verbs and nouns. ${ }^{38}$ This might seem to suggest that Philo does not see the literal form, but only the message as important.

\footnotetext{
37) Yehoshua Amir, "Authority and Interpretation of Scripture in the Writings of Philo," in Mulder and Sysling, eds., Mikra, 421-453, esp. 444.

38) Adam Kamesar, "Philo and the Literary Quality of the Bible: A Theoretical Aspect of the Problem," JJS 46 (1995): 55-68, esp. 58.
} 
If the literary form is a human creation, and the message divine, then the form is not important. However, this conclusion is belied by the way Philo employs allegory in his reading of scripture. Niehoff has shown that when Philo poses questions about the text and answers them with allegory it is often because he is concerned with textual details. ${ }^{39}$ When he encounters turns of phrase that are theologically problematic for him-such as the plural form of verbs of divine subject in the first creation story-he does not brush aside the forms as a mistake in transmission or even a misrepresentation by Moses. The text itself remains constant. He deals with instead by coming up with an allegorical reading of what Philo apparently sees as a fixed textual form. ${ }^{40}$ Though Philo is employing a method that originated among Alexandrian Homeric scholars as a tool of text criticism, he does not utilize it for such purposes. ${ }^{41}$ Problematic passages are taken for granted as part of the text.

Antiquitates 12.11-118

The version Josephus repeats in Antiquitates is a very close paraphrase of his source Aristeas with only a few, rather large omissions, such as the discussion of the law between Eleazar and Aristeas and the symposium between the translators and Ptolemy. ${ }^{42}$ Given this fact, we can take for granted that the laws of the Judeans fit the definition of scripture we have employed throughout. For the most part also, Josephus conceives of the law texts in the same way as Aristeas. He notes that the Hebrew text has been poorly transmitted (12.37), that it is Demetrius' idea to have a reliable version (12.108), and that this is accomplished through the cooperation of scholars of the law (12.39). Josephus also has the Hebrew scrolls emanating from the temple (12.56), and seems to believe they are of a high quality (12.89-90), though Ptolemy here does not prostrate himself before the texts. In this account there is even recognition by the Judean community in Alexandria that the texts have reached a state where they should not be altered (12.108).

\footnotetext{
39) Niehoff, "Questions," 344, 359.

40) Ibid., 359.

41) Ibid., 360.

42) Louis H. Feldman, "Use, Authority and Exegesis of Mikra in the Writings of Josephus," in Mulder and Sysling, eds., Mikra, 455-518, esp. 457-58; Veltri, Libraries, 40.
} 
There is, however a major difference. After this agreement between the priests, translators, elders and leaders of the commonwealth to "freeze" the text in its current state, a provision is added:

When everyone congratulated one another on this resolution, they commanded that if anyone saw something redundant or something lacking in the law that he would look it over once more and unrolling it, make the correction. Doing this was wise so that when it was judged to have been done well, it might continue forever. ${ }^{43}$

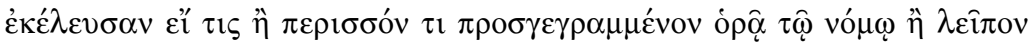

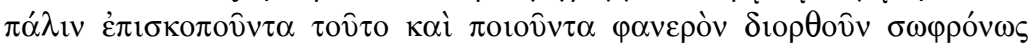

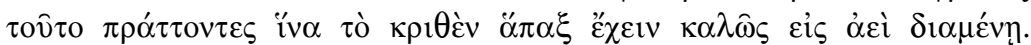
(12.109)

Even though there was a sentiment expressed by these characters to maintain a fixed text, Josephus does not want to concede the point. Either he, or whatever version of the LXX myth he knew added the provision that additions were allowed after all. Even after the text has been approved there is a procedure for making corrections. Now, it may be argued that Josephus or his source envision this as corrections toward a more reliable version of the law. But, then a legitimate question arises as to what text is imagined as the standard against which this one would be judged, if any text at all. How much was allowed under the heading of anything redundant or lacking?

Josephus' version of the LXX myth has, in the end, erased the concept of a fixed textual form. What seems to have been a germinating idea in Aristeas, and an issue of central importance to Philo is pushed aside by Josephus through this editorial remark. That is not to say that Josephus wants to relinquish all control over the textual form in his version. It does seem that these changes must be made by this group and at their approval, but they are changes nonetheless. Even Ptolemy's wish that the texts remain uncorrupted rings hollow after this addition (12.114). Though there are many more versions of this myth known, making even more adaptations to the legend and text, these three early editions have provided interesting insight into attitudes toward the form of the text.

43) Translation by the author. 


\section{Conclusions}

We have now traced the varying attitudes toward textual fixity of scripture through three early versions of the LXX myth. Our study has revealed that, though there are Semitic, Hellenic, and "biblical" precursors to the impulse to freeze the tradition, this myth seems to be the first to apply this desire to the exact textual form of a version of scripture. This might serve as a correction both to maximalists who place the requirement for a fixed textual form early in the history of transmission, ${ }^{44}$ as well as for those who locate this attention to the textual form only in the Christian period..$^{45}$ There is little doubt that the Letter of Aristeas and De Vita Mosis both desire a fixed textual form that communicates the true message. While both of these authors-and Josephus as well-tend to have the LXX in focus throughout this discussion, we do not feel this weakens the impulse found in these texts. These authors all contribute to a myth of the LXX as scripture by assuring their audience that it is at least as reliable a copy of the law as is "the Hebrew version." Aristeas acknowledges that other forms exist, but authorizes only the one translation created under Demetrius and the king. Philo does not even allow for this. For him, there is only one form of the text divinely guided (through inspiration and human intellect) once in Hebrew, and once more in Greek. The need for a fixed form is so strong that he cannot even acknowledge variant traditions. Even if Philo would have conceded the existence of various Hebrew forms (which he probably knew existed) his presentation requires at least one authoritative form that matches the Greek word for word. Rationally thought out, a word for word translation that is identical in form and sense cannot have a freefloating comparison in Hebrew. There must be a solid tradition to which it can point.

This does not mean, however, that we should conclude this is a linear progression through history that must simply be moved earlier or later, depending on what our previous biases have been. Josephus' version of the myth ensures that. He acknowledges multiple versions while telling the story of the authoritative edition created by Ptolemy. He also allows for the fact that even this version of the Judean laws could be adapted as long as it met with the approval of the leaders of the community in Alexandria. While he does seem to desire a stabilized text, it is not so fixed as to be frozen. There are clearly a variety of opinions at play here, even in the

44) Beckwith, "Formation," 41.

45) Sanders, "Issue," 256; Ulrich, "Notion," 24-25. 
ancient receptions of scripture. The way these three examples communicate about this text they consider scripture ensures that. Neither location nor time seem to strongly influence the ways these texts present the attention to textual form of the LXX within the same mythic tradition.

This study does lend support to those who believe a fixed textual form should be divorced from our discussions of scripture and even canon. ${ }^{46}$ All three of these accounts receive the Judean laws as scripture, using the rather stringent criteria laid out by Ulrich. All three have different ideas about textual fixity as well. Aristeas seems to present a desire to have a locally fixed form that is agreed upon by experts to represent the authentic tradition. Philo desires an eternally stabilized textual form, unchanged and unchangeable, transmitted through divine intervention. Josephus seems to desire a high quality textual form, but perhaps correctly thinks the only way this might be achieved is through constant attention to the text for what might be extraneous or lacking. Scriptural status does not safeguard anything regarding the textual form, if the LXX myth is any guide. The textual record we know from outside these accounts supports this. ${ }^{47}$

Where this investigation might have uncovered new ground for further study is in the provenance of the desire for textual fixity. Aristeas like Philo's De Vita Mosis likely comes from a heavily Hellenized community in Alexandria. ${ }^{48}$ Josephus is writing for his Flavian sponsors in Rome. Might it be that the strong desire for an authoritative version, tied so closely to the Alexandrian court in these accounts, has some link to the desire for authoritative versions of texts in the collections at the Serapeum and the Museum? ${ }^{49}$ Support for this proposition may come in the form of the strong association Alexandria has with the allegorical model of exegesis. ${ }^{50}$ It is only once texts find a fixed form (at least in the minds of some) that it becomes necessary to read them symbolically. ${ }^{51}$ Though, obviously this myth does not communicate fact, it may inadvertently give a clue about the Hellenistic world's role in igniting the spark of desire for a stabilized text.

46) Ulrich, "Notion," 28, n. 26.

47) Emanuel Tov, "The Septuagint," in Mulder and Sysling, eds., Mikra, 161-88, esp. 167.

48) Tcherikover, "Ideology," 60-61.

49) Honigman, "Narrative," 136-37, who includes a rather illustrative story from Galen about the lengths to which Ptolemy would go to acquire authoritative copies.

50) Tcherikover, "Ideology," 82.

51) Sanders, "Issues," 258. This would correspond with Sanders' third stage of transmission, wherein God no longer acts within history and so humanity is forced to interact with the text in new ways. 